\title{
A nemzetiségi helységnevek hivatalos használata Magyarországon
}

\author{
Sasi Attila
}

DOI: https://doi.org/10.30921/GK.71.2019.4.4

Absztrakt: Magyarországon egy 2007-es kormányrendelet rendelkezik a nemzetiségi nyelvü hivatalos földrajzi nevek megállapitásáról és nyilvántartásáról. A kormányrendelet megjelenése óta azonban államigazgatási szinten ezeknek a neveknek a megállapítása és nyilvántartása még nem történt meg. Az elmúlt évszázadokban természetes gyakorlat volt Magyarországon az idegen nyelvü helységnevek feltüntetése a térképeken, helységnévtárakban. Nemzetiségi nyelvü helységnévtáblák 1979 óta vannak kihelyezve. A nemzetiségi helységnévtáblákra kiírt nevek nem hivatalosak, csak tájékoztató információt jelentenek. A Központi Statisztikai Hivatal 1995 óta a hivatalos helységnévtárban külön táblázatban közli ezeket a neveket, ma ez az egyetlen állami szintü hivatalos forrás a nemzetiségi helységnevekröl. Magyarországon a központi nyilvántartás készül a kihelyezett nemzetiségi helységnévtáblák alapján, nem pedig egy központilag összeállított helységnévlista alapján kerülnek ki a táblák, mint más közép-európai országokban. A nemzetiségi helységnevek bár a hivatalos magyar helységnévtárban jelennek meg, mégsem tekinthetök hivatalosan megállapított nemzetiségi helységneveknek. A magyarországi nemzetiségi nyelvú hivatalos helységnevek megállapítása csak egy gondos, tudományos munkafolyamat révén lehetséges. A Lechner Tudásközpontnál kezelt Földrajzinév-tár adatbázisa minden hozzáférhetố forrás alapján ki lett egészítve a nemzetiségi helységnevekkel. Ezeket a neveket anyanyelvi, nemzetiségi, nyelvészeti szakértókkel ellenóriztetni kell, hogy a helyi használatnak legmegfelelöbb, nyelvileg leghelyesebb, történetileg leghitelesebb névalak kerüljön kiválasztásra.

Abstract: In Hungary the establishment and registration of official geographical names in the minority languages, are stated in a Government Edict in 2007. However, since the publication of the edict, these names have not been determined and registered by the state department yet. In past centuries it has been a common practice in Hungary to indicate the place names in foreign languages on maps and gazetteers. There have been placed minority road signs since 1979. The place name signs in minority languages are not considered to be official place names, they only provide information. The Hungarian Central Statistical Office is in charge of publishing these names in the official Gazetteer since 1995, that is the only existing official list of the minority place names. In Hungary the central register is made on the basis of the allocated minority town signs, not the town signs are allocated based on an official minority place name list, as it is in practice in other Central European countries. Although these names appear in the official Gazetteer of Hungary, they are not considered to be officially established minority place names. The establishing of the official geographical names in minority language in Hungary is possible only through a careful, scientific workflow. The database of the Gazetteer of the geographical names in Hungary by the Lechner Knowledge Center has been supplemented with the minority place names based on all available sources. These names need to be controlled by minority, linguistic experts, in order to select the most appropriate name based on local use, linguistical correctness and historical legitimateness in case of more allonyms.

Kulcsszavak: nemzetiség, helységnév, helységnévtábla, helységnévtár, földrajzi név Keywords: minority, place name, town sign, gazetteer, geographical name

\section{Kormányrendelet}

Magyarországon a 2007. évi 303. számú kormányrendelet rendelkezik a magyarországi hivatalos földrajzi nevek, ezen belül a nemzetiségi nyelvú hivatalos földrajzi nevek megállapításáról és nyilvántartásáról (korm.-rendelet 2007). A rendelet szerint a megállapított hivatalos magyar és nemzetiségi nyelvú földrajzi neveket a földmérési és térinformatikai államigazgatási szervezetnek kell a Földrajzinév-tárban nyilvántartani. A kormányrendelet megjelenése óta azonban államigazgatási szinten a nemzetiségi nyelvú földrajzi nevek megállapítása és nyilvántartása még nem történt meg.
Magyarországgal ellentétben a szomszédos országok az elmúlt évtizedekben helységnévjegyzékekben tették közzé a helységnévtáblán megjeleníthetô kisebbségi helységneveket, és központi, tartományi kormányhatározatok, rendeletek szabályozzák azok használatát. A kisebbségi nyelvú helységnévtáblákon feltüntetett nevek azonban Szlovénia kivételével nem tekinthetôk hivatalos helységnévnek, hanem csak tájékoztató jellegú megjelölésnek. Használatuk általában a kisebbségnek a település összlakosságán belüli számarányához kötött: Horvátországban 33,33\% (Lábadi 2003, Andócsi 2012), Romániában és Szlovákiában 20\% (Monit. oficial
2001, Zákon 1994, Nariad. vlády 1999), Szerbiában 15\% (MNT 2012), Ukrajnában 10\% (BeregszásziCsernicsk -Ferenc 2014), Ausztriában a rendeletben közzétett helységnevek használhatók (Bundesgesetzblatt 2000), Szlovéniában pedig nincs a kisebbség számarányához kötve a nemzetiségi helységnévhasználat (Uradni list 1991). Távolabbi példaként érdemes megemlíteni Finnországot, ahol egy törvényhatósági területet akkor nyilvánítanak kétnyelvúvé (ami bizonyára a kisebbségi helységnévhasználatot is lehetôvé teszi), ha a nemzeti kisebbség aránya eléri a 8\%-ot, vagy létszámuk a háromezer foót (Andrássy 2012). 
Helységnevek és mikrotoponímia

A földrajzi neveken belül fontos különbséget tenni a helység és helységrésznevek illetve a kisebb földrészletek, vízrajzi elemek nevei (mikrotoponímia) között.

A nemzetiségi helységnevek többnyire ismertek, a hivatalos helységnévtár is közli a helységnévtáblán feltüntetett változatokat (KSH 2019). Ezen túl széles körben használják azokat a nemzetiségi médiában, honlapokon, irodalomban, tudományos munkákban. Az egyes településekról szóló internetes szócikkekben általánosnak mondható, hogy megemlítik a nemzetiségi névalakokat is. Számos turisztikai térképen is feltüntetik a nemzetiségi helységneveket. A nemzetiségek szervezetei, szakértői is számos nemzetiségi névjegyzéket állítottak már össze, térképeket jelentettek meg, az adott nemzetiség helységneveivel. (Cartographia
2015, Davidov 1990, Gyivicsán 1996 Gyivicsán-Krupa 1997, Hambuch 1992, Karagić-Mokuter 1986, KozarMukič 1984, Mandić 2005, PetrusánMartyin-Kozma 1999, RegényiScherer 1980, Sasi 2014, Weidlein 1980). Az egyes nemzetiségek anyaországaiban megjelenô kiadványokban, térképeken úgyszintén sok esetben használják a magyarországi nemzetiségi neveket, ugyanígy a google.com különbözó nyelvi változatú térképein is. Mivel a Google-térképek gyakorlata a helységneveket illetően az egynyelvúség, ezért ezeken a térképeken a nemzetiségi helységnevek a települések egyetlen elnevezéseként jelennek meg. Ezáltal és a nemzetiségi helységnevek körében uralkodó rendezetlenségek miatt, sajnos sok esetben téves, bizonytalan hitelú elnevezések terjednek el a köztudatban.

A nemzetiségi nyelvú mikrotoponímiai névanyagot különböző helytörténeti munkákban, földrajzinév-gyújtési kötetekben (Balogh-Ördög 1985, Hajdú 1982, Pesti 1982, Végh-Ördög-Papp 1981), régi kataszteri és katonai térképeken (Mapire 2019) vagy egyes újabb kiadású településtérképeken lehet megtalálni. Országos szinten pedig már több évtizede folyik a nemzetiségi nyelvú névanyagra is kiterjedố mikrotoponímiai névgyújtési terepi munka a magyar Földmérési és Távérzékelési Intézetnél és jogutódjainál.

\section{Történeti áttekintés}

A múltban, évszázadokon keresztül természetes gyakorlat volt Magyarországon az idegen nyelvú helységnevek, helynevek feltüntetése a térképeken és helységnévtárakban. Kezdetben ez csak a latin és német névváltozatok használatát jelentette, mivel Magyarországon 1844-ig a latin volt a hivatalos államnyelv és a Habsburg fennhatóság miatt pedig a német is a közigazgatás nyelve volt. A 18 . század

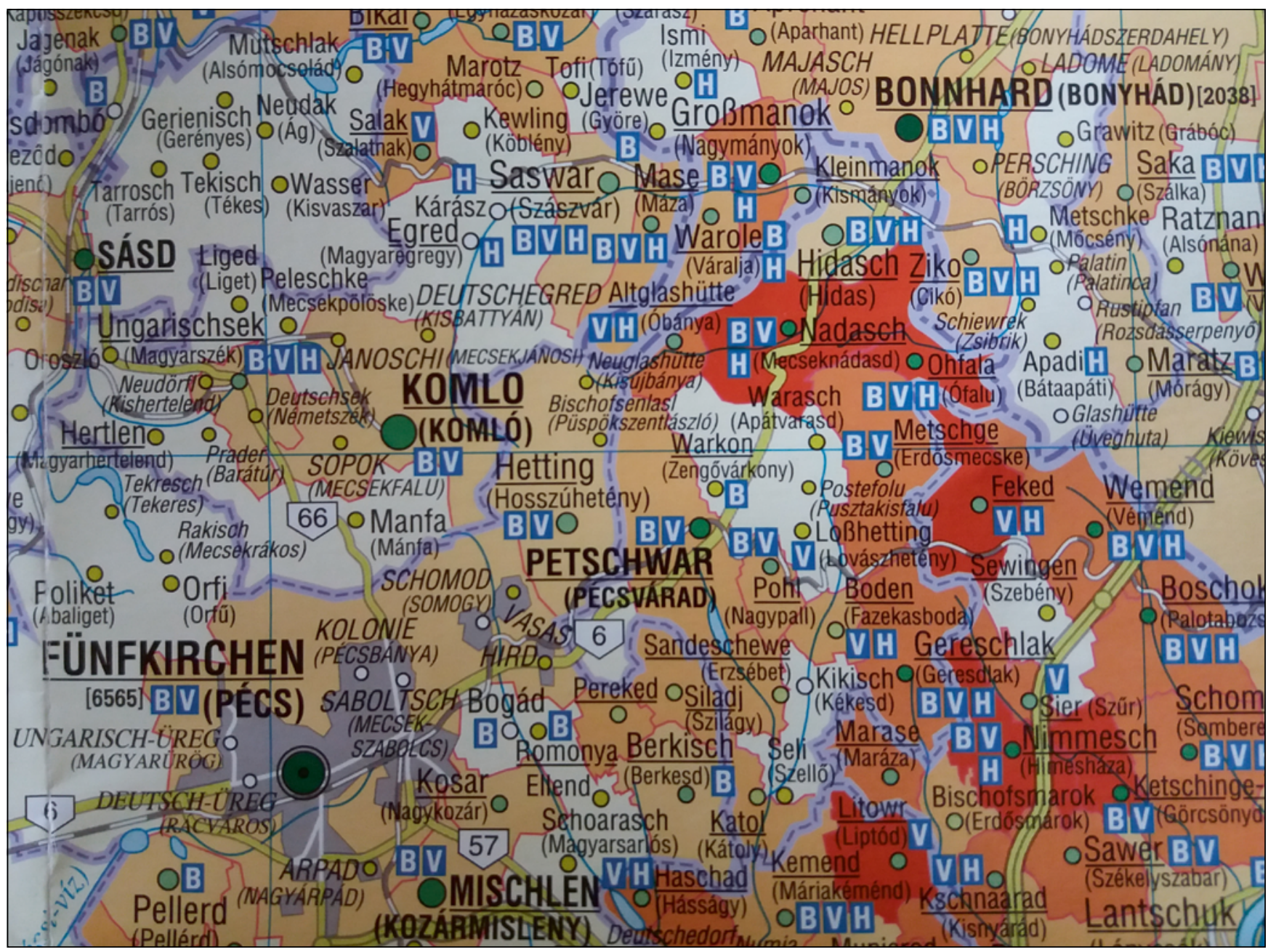

1. ábra. Részlet A magyarországi németek térképe 3. kiadásából 
végétôl azonban már az egyéb (szláv és román) helységneveket is használták, ami már valódi kisebbségi helységnévhasználatnak tekinthetô.

Már az elsô önálló Magyarországtérképen (Lázár 1528) találkozunk többnyelvú helységnévmegírásokkal, pl. német/latin (Pécs: Funff Kirchen/ Quinqz Ecclesiae, Esztergom: Gran/ Strigoniu, Székesfehérvár: Alba Regalis/ Stuell Weißnburg), vagy magyar/ német (Magyaróvár: Owar/Altenburg, Kolozsvár: Coloswar/Clausenburg).

Zsámboki János 1566-ban Bécsben kiadta Honterus 1532-ben készült múvének, az elsố Erdély-térképnek újrametszett másolatát (Zsámboki Erdély 1566). A térkép hátoldalán pedig elhelyezett egy rövid ismertetôt Erdélyrôl Brodarics István és Antonio Bonfini tollából. Ez egy olasz nyelvú könyv 109. oldala, amelynek az alján található egy magyar, német, latin háromnyelvú helynévtár. A magyarországi térképtörténetben ez tekinthetô az elsố helynévtárnak, amely mindjárt egyben többnyelvú is. A lista 60 földrajzi nevet tartalmaz: Erdély nevén (Erdel/Sibenburgen/ Dacia ripensis/Pannodacia/Trans. vel Vltrasiluania) kívül 46 helységnevet, pl. Marosvásárhely (Zekluasarhel/ Neumarkh), Kolozsvár (Kolosuar/

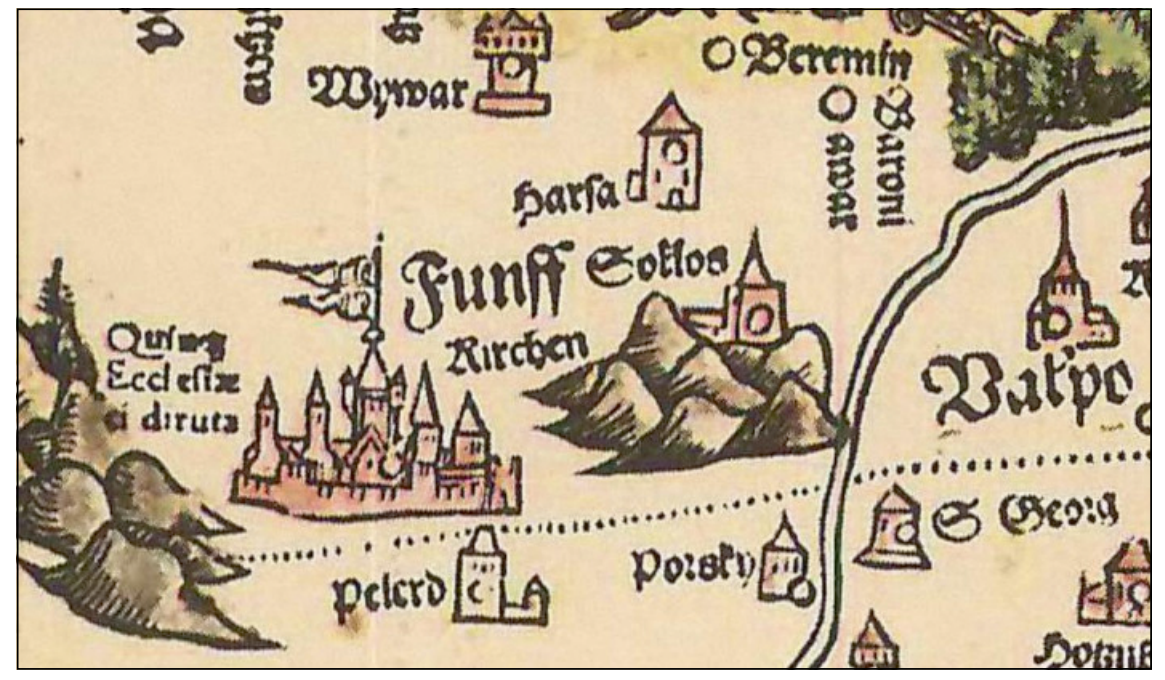

2. ábra. Pécs környéke Lázár deák térképén

Clausnburg/Claudiopolis) vagy Nagybánya (Nagbanya/Newsteetl/ Riunli domin), 10 folyónevet, pl. Maros (Maros/Merisch/Marysus fl.) vagy Körös (Keureuz/Die Kraysz/ Chrysius fl.) és 3 tájnevet, mint pl. a Barcaság (Barczasagh/VVurtzland/Burcia).

Mivel a helynévtár eredendően egy könyv részlete, ezért a nevei viszonylag függetlenek a térkép névanyagától. A térképen jóval több, 302 megnevezett földrajzi hely van, s a helynévtár 60 földrajzi helyébôl csak 47 található meg a térképen is. Tehát mindössze 16\%-os az átfedés. Nyelvileg is nagy a különbség, hiszen amíg a helynévtár alapvetôen magyar nyelvú, kiegészítve német és latin névváltozatokkal, addig a térképen legnagyobbrészt csak németül vannak feltüntetve a földrajzi helyek. Fontos megjegyezni, hogy Zsámboki még ugyanebben az évben kiadta Lázár deák térképének átdolgozott másolatát is (Zsámboki Magyarország 1566). Ezen a térképen is, a jobb alsó szélén egy oszlopba rendezve elhelyezték a háromnyelvú névmutatót. Ez ugyanaz a 60 név kisebb helyesírási változtatásokkal. Természetszerúleg a Magyarországtérkép még kevesebb nevet tartalmaz

\section{Alcuni vocabuli di roce differente, che pero fignificano liffeffo, di Tran filuania, Vngari, Tedefchi, \& Latini,notatidal Sambuco.}

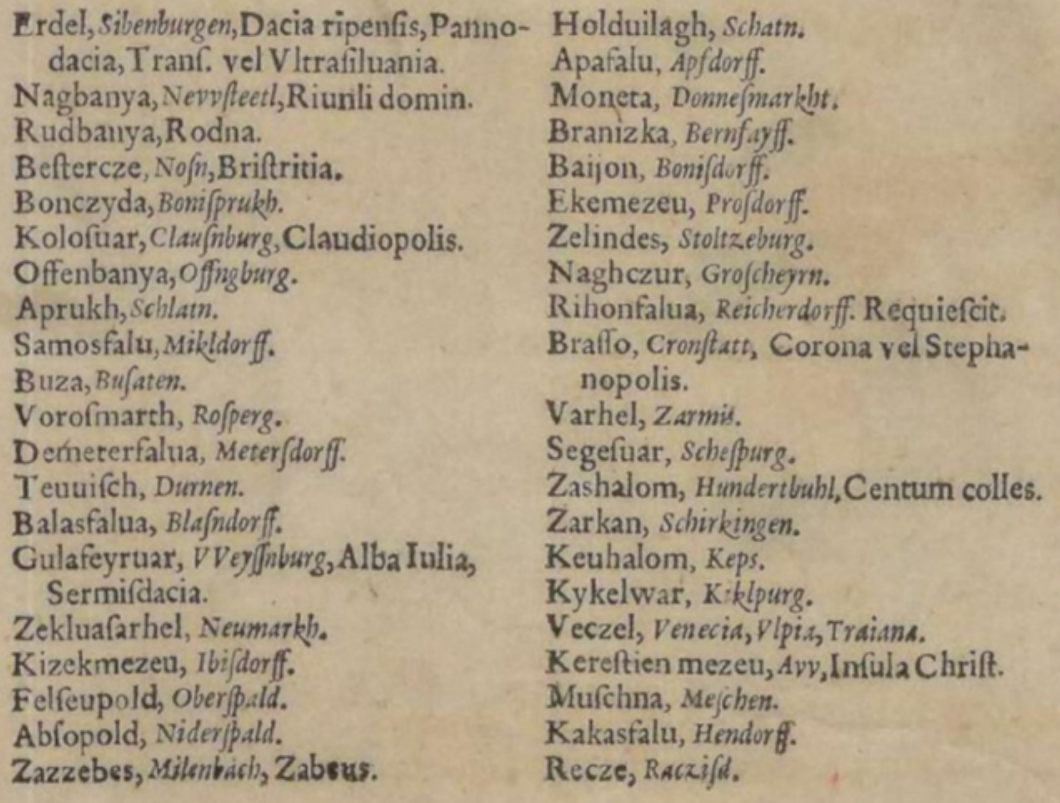

Ioffii, Val. Dobrà.

Vizakna, Salzburg.

Barczafagh, VVurtzland, Burcia.

Vaskapu, Eyfuthor,Pilx Geticx veteribut.

Veuroftorn, Ratertuern.

Zakadat, Zaka.

Feketetho, Nigra palius

Tolmacz, Talmifch.

A ran, Auratusfl.

Zamos, Samijcb, Safriofus ff.

Keureuz, Die Krayjz, Chryfius fi.

Feyer $\}$ keureus, $\left\{\begin{array}{l}\text { vveis } \\ \text { folvvvartz }\end{array}\right\}$ krey $\int$ :

Sebes keureus, die fobncl kray $z \mathrm{fl}$.

Maros, Merifch, Maryfus fl.

Olt, Die Alth, Aluata, Aluttus fl.

Strel, Iftrig,Sargetia, vel potiùs Strigetia ff:

Ompay, die Omp, fl.

Haczagh, vel Hathfaag, vallis Sarmijis vbi fuit ciuitas Sarmiggethufa, boc.

3. ábra. A háromnyelvü helynévtár Zsámboki János Erdély térképének hátoldalán 
a névtár neveiból, minden bizonnyal egyszerúen csak helykitöltés gyanánt került a térkép mellé.

Az első helységnévtár, amely Magyarország valamennyi települését és azok legfontosabb adatait összeírta, az az 1773-ban elkészült Lexicon universorum Regni Hungariae locorum populosorum (Lexicon 1773). Ebben a helységek latin, magyar és német elnevezései mellett már közlik a szláv és román névalakokat is. Ez a gyakorlat a XX. század kezdetéig meg is maradt a helységnévtárakban, térképi névmutatókban.

Az 1898. évi IV. törvénycikk (Törvény 1898) kimondja, hogy Magyarországon minden községnek csak egy hivatalos neve lehet. Az államigazgatás szempontjából ez fontos intézkedés volt, de sajnos együtt járt a helységek egyéb névváltozatainak, így a nemzetiségi neveknek a hivatalos megszüntetésével. A történelmi Magyarországon az 1902. évi helységnévtár volt az utolsó, amely még tartalmazott nemzetiségi helységneveket. Ezt követôen a II. világháború idôszakát leszámítva, a Magyar Köztársaság 1995-ben kiadott hivatalos helységnévtárában jelentek meg újból a nemzetiségi helységnevek (KSH 1995).

\section{Nemzetiségi helységnévtáblák}

Magyarországon a nemzetiségi helységnévtáblák kihelyezését az 1970es években a nemzetiségi szövetségek, az érintett községek tanácsai, a megyei hivatalos szervek és az országos Földrajzinév-bizottság közötti többszöri egyeztetés elôzte meg (Kult. Min. 1978). Ennek eredményeképpen 1979ben mintegy 180 településen helyeztek ki nemzetiségi nyelvú helységnévtáblákat. Ezeknek a száma napjainkra több mint 300-ra nốtt, és országszerte kilenc nyelven (német, szlovák, horvát, szerb, román, szlovén, bolgár, görög és ruszin) láthatók nemzetiségi helységnevek a helységnévtáblákon.

A kezdeti gyakorlattal ellentétben jelenleg a nemzetiségi helységnévtáblák kihelyezéséhez nem szükséges semmilyen központi engedély vagy egyeztetés, a nemzetiségi névalak megállapításához semmilyen szakmai

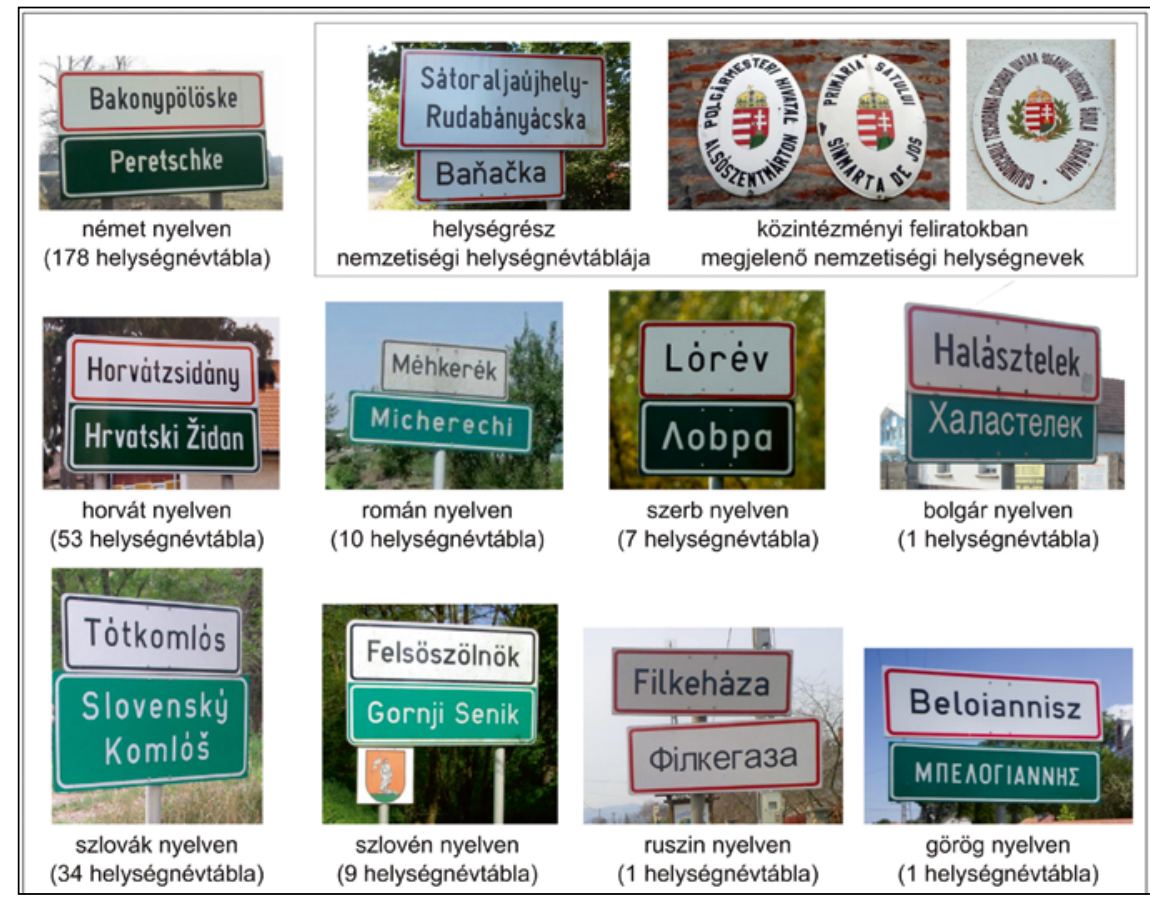

4. ábra. Nemzetiségi nyelvú helységnévtáblák Magyarországon a 2010-es években

vélemény. Az adott nemzetiségnek semmilyen részarányt nem kell elérnie a helység lakosságán belül. Teljes egészében az adott helység önkormányzatának a hatáskörébe tartozik az ügy, csak a tábla kihelyezéséhez kell engedélyt kérni a közutat felügyelô állami szervtől. A nemzetiségi helységnévtáblákat idônként le is cserélik, ha az elôször kihelyezett táblán nem az ott élők által használt névalak volt. A baranyai Véménden (Wemend) kezdetben a szomszéd német faluban használt német nevet (Weimend) írták ki, mert annak a falunak a hivatala intézte az ügyet. A Csepel-szigeti Szigetújfalun pedig a magyar név német tükörfordítását írták ki (Inselneudorf), mert a nyelvjárási alakot (Ujfluch) nevetségesnek gondolták. Ma pedig mind a kettô tábla ki van helyezve.

Néha egészen csekély számú, akár 5\%-ot vagy 10 fôt sem meghaladó nemzetiségi népesség esetén is ki van helyezve nemzetiségi helységnévtábla, mint például Vekerden (román neve Vecherd) 3 román (2,4\%), vagy Kercseligeten (német neve Gerstleck) 6 német (1,5\%) lakos esetén. Más esetekben pedig jelentôs, vagy éppen többségi nemzetiségi lakosság esetén sincs nemzetiségi helységnévtábla, mint például a nógrádi Csôváron (szlovák neve Čúvár), amelyik az egyetlen abszolút szlovák többségú falu (320 fô,

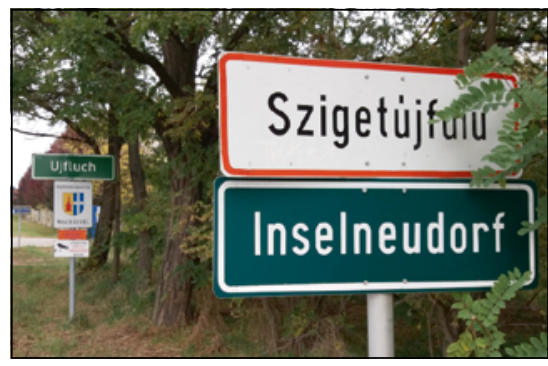

5. ábra. Szigetújfalu helységnévtáblája 2018-ban

51\%) Magyarországon a 2011-es népszámlálási adatok szerint (KSH 2014). Ugyanígy a 70\%-ban német (147 fô) lakosságú Keszőhidegkút nemzetiségi neve (Hiewrkut vagy Hirekut) sincs kiírva. A legnagyobb magyarországi nemzeti kisebbség (316 ezer fó, becsült létszámuk 500-800 ezer fô), a romák nyelvén (sem romani, sem beás nyelven) egyáltalán nincsenek nemzetiségi helységnévtáblák. Mindezek miatt a nemzetiségi helységnévtáblák által megjelenített nyelvi tájkép nem a valós nemzetiségi viszonyokat tükrözi.

Sokszor a települések közintézményein is megjelenik a nemzetiségi név, akár olyan esetben is, amikor nemzetiségi helységnévtábla nincs. Ilyen eset fordul elố a Pest megyei Csobánkán, ahol helységnévtáblán nem, de az iskolán három nyelven is olvashatók a település nemzetiségi nevei (németül Tschobanka, szerbül Чобанац, szlovákul Čobánka). Megjegyzendô, hogy 
a német név helyesebben Tschowanka. De olyan is elôfordulhat, hogy más alakban van a közintézményi táblán és másként a helységnévtáblán, mint pl. a baranyai Felsôszentmártonban, amelynek horvát neve a helységnévtáblán Martinci, az iskolán Martince. Olykor csak a helység határában lévố üdvözlôtáblán vagy a településen belüli információs táblán olvashatók a nemzetiségi helységnevek, mint például Bakonygyiróton (németül Gyrolth) vagy Bakonynánán (németül Nannau).

A nemzetiségi helységnevek mellett nemzetiségi utcaneveket is láthatunk, ezeknek a használata még kevésbé szabályozott, nyilvántartás sincs róluk. Az utcanévtáblákon néha egészen példaértékúen a magyar név mellett a nemzetiségi nevet irodalmi és nyelvjárási formában is feltüntetik, ahogy ez Pilisvörösváron (németül Werischwar) látható, mint például a Csobánkai utca/ Tschowankaer Straße/Tschuwanga Schtroosn vagy a Szent Erzsébet utca/ Sandauer Straße/Sandama Schtroosn tábláin (Müller 2013). Az előbbi példák annyiban is különlegesek, hogy a szomszédos települések helyi német elnevezése is megjelenik az utcanevekben (Csobánka/Tschowanka, Pilisszántó/ Sandau).

\section{Magyarország helységnévtára}

A Központi Statisztikai Hivatal 1995 óta a hivatalos helységnévtárban külön táblázatban közli a nemzetiségi nevet a helységnévtáblán feltüntetô helységek jegyzékét (KSH 1995, 2019). Ma ez az egyetlen állami szintû hivatalos forrás a nemzetiségi helységnevekről. A helyzet tehát pont fordított, mint más közép-európai országokban. Magyarországon a központi nyilvántartás készül a kihelyezett nemzetiségi helységnévtáblák alapján, nem pedig egy központilag összeállított helységnévlista alapján kerülnek ki a táblák.

Ez a lista az egyes települések hivatali adatközlésén alapul, a település jegyzóje hitelesíti. A Központi Statisztikai Hivatal az ily módon beérkezett adatokat közli, azokat nem áll módjában ellenórizni. Ebből kifolyólag sajnos a jegyzék nem tartalmazza

\begin{tabular}{|ll|}
\hline A HELYSÉGEK - HELYSÉGNÉVTÁBLÁRA KIÍRT & - NEMZETISÉGI NEVEINEK LISTÁJA \\
\hline Agendorf (Ágfalva) & Ahlaß (Olasz) \\
Alkár (Mátraszentimre) & Almasch (Bácsalmás) \\
Andovci (Orfalu) & Apateu (Körösszegapáti) \\
Ata (Áta) & Atscha (Vértesacsa) \\
Baćin (Bátya) & Bätania (Battonya) \\
Bawarz (Babarc) & Bedeu (Bedö) \\
Békéšska Čaba (Békéscsaba) & Berkina (Berkenye) \\
Bikić (Bácsbokod) & Bizonja (Bezenye) \\
Bogdan (Dunabogdány) & Bohl (Bóly) \\
Bootsch (Pócsa) & Boschok (Palotabozsok) \\
Burjad (Borjád) & Cenadul Unguresc (Magyarcsanád) \\
Chitighaz (Kétegyháza) & Čkerija (Csikéria) \\
Deutschhütten (Németbánya) & Deutschpilsen (Nagybörzsöny) \\
Dewrenten (Döbrönte) & Dolné Petany (Alsópetény) \\
Donaudorf (Dunafalva) & Dušnok (Dusnok) \\
\hline
\end{tabular}

6. ábra. Nemzetiségi helységnevek a KSH helységnévtárában

az összes helységnévtáblára kiírt nemzetiségi helységnevet. A több mint 300 nemzetiségi helységnévtáblából 261 van a listában. Például Csömör határában mind a szlovák (Čemer), mind a német (Tschemer) neve ki van írva, de a helységnévtár ezeket nem közli. Másrészt többször nem abban a formában adja meg a nemzetiségi neveket, ahogy azok valóban ki vannak írva a helységnévtáblán (pl. Battonya, román neve a helységnévtárban Bätania, a helységnévtáblán helyesen Bătania). Az is elófordul, hogy a helységnévtári listában szerepel egy helység nemzetiségi névvel, de a valóságban nincs kitéve nemzetiségi helységnévtábla (pl. Szigetcsép, német neve: Tschip, szerb neve: Чип). Ha a helységnévtáblákon feltüntetett nemzetiségi név nyelvileg, nyelvtanilag nem helyes, akkor azt többnyire a helységnévtár is ugyanúgy közli, de arra is van példa, hogy mind a helységnévtár, mind a helységnévtábla helytelen formát ad meg (Farkasgyepú, német neve helyesen: Wirtshäusl, a helységnévtárban Wirtshäuz'1, a helységnévtáblán Wirtshäuzl'). A helységnévtár nem tartalmazza a helységrészek helységnévtáblán kiírt nemzetiségi neveit, mert a hivatali adatgyújtés nem terjed ki a helységrészekre. Ugyanakkor mintegy húsz nemzetiségi lakosságú falu van, ami jogilag egy közeli város része, de van saját nemzetiségi helységnévtáblája is, mint például a Tatához tartozó Agostyán (németül Augustin), az Esztergomhoz tartozó Pilisszentlélek (szlovákul Hut', a helységnévtáblán hibásan Hute) vagy a Szentgotthárdhoz tartozó Rábatótfalu (szlovénül Slovenska Ves) esetében.
Mivel a nemzetiségi helységnevek hivatalos megállapítása még nem történt meg, Magyarországon továbbra is csak egy hivatalos nevük van a településeknek. A nemzetiségi helységnévtáblákra kiírt nevek nem hivatalosak. Így elmondható, hogy a nemzetiségi helységnevek bár a magyar Központi Statisztikai Hivatal által közölt hivatalos helységnévtárban jelennek meg, mégsem tekinthetôk hivatalosan megállapított nemzetiségi helységneveknek.

\section{Földrajzinév-tár}

A magyarországi nemzetiségi nyelvú hivatalos helységnevek megállapítása még egy elvégzendô feladat. Ennek elsố lépéseként a Földmérési és Távérzékelési Intézet jogutódjánál kezelt Földrajzinév-tár adatbázisa a fellelhetô források alapján ki lett egészítve a nemzetiségi helységnevekkel. A hivatalos helységnévtárral szemben, amely 242 helység 261 nemzetiségi nevét közli 8 nyelven, a Földrajzinévtár adatbázisa 1298 helység és 569 helységrész 3425 nemzetiségi nevét tartalmazza 12 nyelven. A nevek legnagyobb része német, horvát és szlovák. Nagyobb számban vannak még roma, szerb, román, szlovén és ruszin helységnevek, lengyel, görög és bolgár nevekből csak néhány fordul elô. A törvényileg elismert 13 magyarországi nemzetiség közül ukrán és örmény nyelven nincsenek nemzetiségi helységnevek, illetve roma nevek két nyelven (romani és beás) is vannak.

A Földrajzinév-tár adatbázisa a földrajzi nevek adatállományára vonatkozó 2014-es INSPIRE-ajánlás szerint 
Sasi Attila: A nemzetiségi helységnevek hivatalos használata Magyarországon

\begin{tabular}{|c|c|c|c|c|c|c|c|c|}
\hline Azonositc - & Név & Nemzetiségi_név1 . & $\mathrm{Ny}$. & Stấ - & For - & Nemzetiségi_név2 . & $\mathrm{Ny}$. & Stá - - \\
\hline 4064 & Beremend & Behrend & ger & $2 ;$ & 406 & Bermend & ger & 84 \\
\hline 80055 & Buda & Ofen & ger & 81 & 443 & Budin & slo & 84 \\
\hline 19487 & Budapest & Budapešt & slo & 81 & 506 & Budimpešta & hrv & 84 \\
\hline 49864 & Vác & Waitzen & ger & $11 \mathrm{~L}$ & 408 & Vacov & slo & 111 \\
\hline 20628 & Hódmezôvásárhely & Vášárhel & slo & $11 \mathrm{l}$ & 426 & Vašrelj & hrv & 131 \\
\hline 34205 & Gyöngyös & Dindeš & slo & $11 \mathrm{~L}$ & 426 & Đunđuš & hrv & 131 \\
\hline 22235 & Adony & Adam & ger & 81 & 406 & Џунтаран & srp & 108 \\
\hline 1821 & Kecskemét & Kečkemit & hrv & $13 L$ & 400 & Kečkemet & hrv & 131 \\
\hline 6165 & Majs & Maisch & ger & 25 & 406 & Majša & hrv & 131 \\
\hline 7131 & Pécsvárad & Petschwar & ger & $2 ;$ & 406 & Pečvar & hrv & 131 \\
\hline 4767 & Erdốsmecske & Metschge & ger & $2 ;$ & 407 & Ratzmetschke & ger & 84 \\
\hline 4988 & Cselegörcsöny & Ketschinge & ger & 81 & 407 & Garčin & hrv & 131 \\
\hline 4723 & Egyházaskozár & Kosart & ger & 81 & 19 & Ratzkosar & ger & 84 \\
\hline 49571 & Tököl & Tukulja & hrv & $2 ;$ & 401 & Tekele & ger & 108 \\
\hline
\end{tabular}

a nemzetiségi neveket jellegük szerint négy csoportban különíti el:

1. „hivatalos” (official)

2. „szabványosított” (standardised),

3. történelmi (historical),

4. egyéb (other).

Az elnevezések nem teljesen fedik a tartalmat, hiszen Magyarországon a nemzetiségi helységnevek szabványosítása és hivatalossá tétele még nem történt meg. A „hivatalos” nevek alatt egyelôre a helységnévtáblán kiírt nevek értendôk, beleértve a KSH hivatalos helységnévtárában közölt nemzetiségi neveket. A „szabványosított” nevek alatt a helységnévtáblákra nem kiírt, de a nemzetiségek által ismert és használt nemzetiségi nevek értendôk nemzetiségi jellegú települések esetén. A történelmi nevek alatt a nem jellemzóen nemzetiségi települések nemzetiségi nevei értendôk, amelyeket az adott nemzetiség ismer és használ. Az egyéb kategóriába az országosan nem ismert, csak a helyi közösségben használt, a szomszédos településekre vonatkozó nemzetiségi helységnevek kerültek.

Eredetük alapján beszélhetünk történelmi, nyelvjárási és mesterséges nemzetiségi helységnevekrôl. Ez a felosztás nem felel meg az adatbázisban használt jelleg szerinti megkülönböztetésnek, hiszen egy történelmi eredetû név élő nemzetiségi névhasználat alapján lehet akár „hivatalos” vagy „szabványosított” is, vagy a nyelvjárási eredetú nevek jellegük szerint a „hivatalos”, „szabványosított” vagy az egyéb csoportba is sorolhatók. A nemzetiségi helységnevek jellemzésére viszont ez a hármas felosztás megfelelôbb.

A történelmi névalakok akár több évszázados írott formával is rendelkeznek, a múltban szerepeltek térképeken, helységnévtárakban. Ezek többnyire a magyar névtôl eltérô eredetúek és az ilyen településeknek csak egy része valóban nemzetiségi jellegú. Ilyen nevek például a nagyobb városok német nevei, mint Pécs/Fünfkirchen, Buda/Ofen, Esztergom/Gran, Eger/Erlau vagy a nyugat-magyarországi német helységnevek, mint például Hegykő/ Heiligenstein, Kiszsidány/Roggendorf. A magyar lakosságú Hegykô történelmi eredetú német neve történelmi jelleget kapott a Földrajzinév-tárban, de a német lakosságú Kiszsidány történelmi eredetú német neve viszont az ún. hivatalos jelleget kapta. Fontos megjegyezni, hogy a történeti források olykor több különbözố névalakot is megadnak egy településhez: pl. Csörötnek/ Schreitling, Schrödling, Schrietling, Schriedling.

A magyarországi nemzetiségi településnevek többsége eredetére nézve a nyelvjárási névalakok csoportjába sorolható. Túlnyomóan ezek a nemzetiségek által most vagy a közelmúltban lakott települések élô, használt nemzetiségi nevei. Írott alakjuk a közelmúltig nem létezett, a helységnévtárak, térképek nem tartalmazták óket. A XX. század második felében kezdtek el terjedni egyes nemzetiségi kiadványokban. Legkorábban Pesty Frigyes 1864-65-ben összeállított kérdőíves névgyújteményében fordultak elô ilyen típusú nevek, például Budaörs német neve Wudaers formában, Tököl rác neve Tukulya formában vagy Pilisszentkereszt szlovák neve Mlinki formában (Pesty 1984). A közelmúlt kiadványai közül többek között a megyei földrajzinév-gyújtési kötetek szolgálnak kiváló forrásul ezekhez a nevekhez, fóként a Baranya és Tolna megyei kötetekben vannak tudományos alapossággal összegyújtve a nemzetiségi helynevek (Pesti 1982, VéghÖrdög-Papp 1981). A nyelvjárási névalakok többnyire a jelenlegi (pl. Bonyhád/Bonnhard, Pilsszántó/Santov, Tököl/Tukulja) vagy korábbi magyar helységneveknek (pl. Máriahalom/ Kirwall, 1936-ig a hivatalos magyar neve Kirva) a kisebbségi nyelv kiejtéséhez igazított hangtani változatai, vagy esetleg a népi etimológia alapján „értelmesített” változata (pl. Isztimér/ Ißzimmer). De a nemzetiségi névalak természetesen lehet egy korábbi más nemzetiségi névalaknak is a változata, mint például Diósd német neve (Orasch), ami az eredeti magyarból fordított egykori rác név átvétele (dió horvátul orah). A nyelvjárási névalakok továbbá sok esetben a magyar névnek a kisebbségi nyelv helyesírásával leírt változatai (pl. Vecsés/Wetschesch, Mohács/Mohatsch/Mohač), amelyek néha írásképükben is teljesen 


\begin{tabular}{|c|c|c|c|c|c|c|c|c|}
\hline Fo. & Nemzetiségi_név3 - & Ny - & Sti $\cdot \cdot$ & For - & Nemzetiségi_név4 - & Ny. & Stá - · & Fo - \\
\hline 19 & Bréminá & rud & 84 & 472 & Бреме & srp & 103 & 418 \\
\hline 506 & Budim & hrv & 84 & 501 & Будим & srp & 81 & 505 \\
\hline 401 & Budapesta & rum & 84 & 512 & Будимпешта & srp & 81 & 505 \\
\hline 426 & Vacija & hrv & 1311 & 400 & Вац & srp & 103 & 416 \\
\hline 400 & Vašarelj & hrv & 1311 & 400 & Вашархељ & srp & $11 \mathrm{~L}$ & 416 \\
\hline 400 & Ћенћеш & srp & 1111 & 416 & Дёндёш & rue & 81 & 433 \\
\hline 418 & Адоњ & sip & 108 & 418 & Дунаадоњ & srp & 103 & 508 \\
\hline 400 & Kečkemerac & hrv & 1311 & 400 & Кечкемет & srp & 81 & 505 \\
\hline 400 & Majiš & hrv & 1311 & 400 & Мајш & srp & 103 & 418 \\
\hline 400 & Pečvaradin & hrv & 1311 & 19 & Печвар & srp & 103 & 416 \\
\hline 406 & Мечка & srp & 108 & 418 & Рацмечка & srp & 103 & 416 \\
\hline 400 & Gerčin & hrv & 1311 & 400 & Српски Гарчин & srp & 103 & 416 \\
\hline 406 & Рацкозар & srp & 1111 & 416 & Српски Козар & srp & 11\llcorner & 416 \\
\hline 443 & Teckel & ger & 6 & 406 & Тукуља & srp & $6 \mathrm{~L}$ & 505 \\
\hline
\end{tabular}

\section{7. ábra. Részlet a Földrajzinév-tár} adatbázisából azonosak a magyar helységnévvel (pl. Narda/Narda). A névalakok tekintetében sokszor nagy a bizonytalanság a különbözô adatgyújtőknek és adatközlőknek köszönhetôen. Jól példázzák ezt Almamellék falu német névváltozatai: Homelik, Homeli, Homelk, Homeling, Momelik.

A nyelvjárási neveknek egy sajátos fajtája az, amikor egy nemzetiségi település lakói a saját nyelvükön elnevezik a környezô, más nemzetiségek által lakott helységeket, amely nevek az ott lakók körében teljesen ismeretlenek.

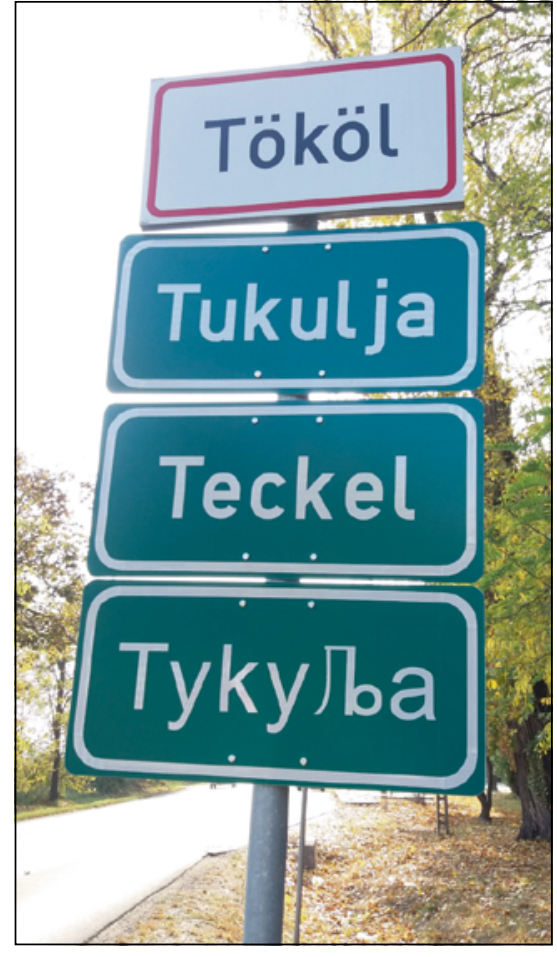

8. ábra. Tököl négynyelvü helységnévtáblája
Ezek a nevek az adatbázis egyéb kategóriájába kerültek. Már Pesty Frigyes is kifejezetten rákérdezett az ilyen jellegú nevekre, kérdőivén a 2 . kérdés így hangzott (Pesty 1984): „A községnek, városnak hányféle neve él most; melyik neve bir csak helybeli elterjedéssel, melyik ismeretes országszerte. - Sajátos jelenség, hogy a magyar és román falvak a körülfekvó szász falvak által Erdélyben német elnevezést nyernek, mely elnevezésrốl az illetố magyar és román falvak lakosainak sejtelmük sincs, mely név különben is csak kis elterjedéssel bir. Viszont sok szász és román falu magyar névvel is bír, mirôl az illetố szász és román falvaknak tudomásuk nincs. Ily viszonyok az ország minden részeiben foroghatnak fenn, hol több ajkú a lakosság, azért felemlítendók.” Ez a névtípus fóleg a horvát nevek körében nagyszámú, köszönhetôen annak, hogy a Živko Mandić magyarországi horvát kutató által összeállított horvát helységnévgyújteményben szereplố 1300 magyarországi horvát helységnév közül mintegy 1000 név ebbe a kategóriába sorolható (Mandić 2005). Ezek a nevek az internetes oldalakon is megjelennek, $s$ némileg zavart is keltenek. Jó példa erre, hogy egy internetes szócikkben az egykor teljesen német lakosságú Budaörs német neve (Wudersch) mellett 3 horvát névváltozat is (Jerša, Erša, Vundeš) szerepel. Ez így mindenképp félrevezetô, mert itt nem volt horvát lakosság, a horvát neveket távolabbi horvát lakosságú településeken
(Tökölön,

Érden, Ercsiben és Csepelen) jegyezték fel (Mandić 2005).

A roma helységnevek is alapvetően a nyelvjárási nemzetiségi nevek közé sorolhatók. Közülük mintegy kilencven van az adatbázisban, de ez közel sem tekinthetố teljesnek. A roma földrajzi nevek gyújtése, kutatása folyamatban van, egyes szakmunkákban lehet néhány példát találni, mind a romani mind a beás nevekre (Arató 2013, Kemény 2000, Orsós 2003). Minden bizonnyal több száz roma helységnév van Magyarországon, hiszen közel 1200 településen múködik roma nemzetiségi önkormányzat, a 2011-es népszámlálási adatok szerint pedig 31 roma többségú település van és további 226 helységben haladja meg a részarányuk a 20\%-ot. Egyedül a legnagyobb arányban (98,6\%, 1140 fó) romák által lakott magyarországi településen, a baranyai Alsószentmártonban látható roma (beás) helységnév közintézményi feliratként kiírva Sînmarta de Jos alakban, de beás kiejtés és helyesírás szerint Szîmártă dă Zsosz lenne a helyes (Arató 2013).

Külön csoportba kell sorolni a mesterségesen alkotott nemzetiségi neveket, amelyek hacsak nincsenek helységnévtáblán feltüntetve, nem kerültek bele az adatbázisba. Fóként a német nevek között fordulnak elő ilyen típusú nevek, amelyeket a következô példák szemléltetnek. A Veszprém megyei Hárskút község 1956-ban jött létre a Szentgálhoz tartozó Hárságypuszta és 
a Lókúthoz tartozó Gyertyánkút külterületekből. Mindkét külterületnek van német nyelvjárási neve: Hárságypuszta/ Haschad, Gyertyánkút/Jitjankut. A magyar név (Hárskút) hivatalos névadás eredménye, amit lefordítottak németre (Lindenbrunn), s ma ez van kiírva a nemzetiségi helységnévtáblán a nyelvjárási Haschad-Jitjankut helyett. Lókút község nyelvjárási német neve a magyarból való (Lokut), de a helységnévtáblán a helyiek által nem használt tükörfordítás olvasható (Rossbrunn). Baja város nyelvjárási német neve Baje, de mégis a mesterséges Frankenstadt az elterjedtebb, pedig ez a névalak egy középkori latin Franca Villa névalak fordításával és rossz beazonosításával jött létre, mert Franca Villa egy Bajától délre fekvő mai szerbiai település Манђелос/Nagyolaszi latin neve volt. Egy másik példa a Maisbrünn alak, ami Mezőberény nevének előzmények nélküli tudatos germanizációja. Helyi nyelvjárási formája Berin, s a nemzetiségi helységnévtáblán is így van. Hódmezóvásárhely esetében az írott médiában gyakran feltúnik a Neumarkt an der Theiß névalak, holott a városnak hagyományosan nincs is német neve. Ezek a nevek sajnos az internetes térképi oldalakon is sokszor előfordulnak, és így széles körben terjednek.

Az adatbázis a nemzetiségi elnevezéseken kívül természetesen még tovább bővíthetố más idegen nyelvú helységnévváltozatokkal is. A nagyobb városoknak több más nyelven is van saját elnevezése (pl. Pécs csehül Pětikostelí, litvánul Pèčas, Gyốr olaszul Giavarino, Székesfehérvár csehül Stoličný Bělehrad). Nagyon gazdag a latin elnevezések köre, ahol fontos elkülöníteni a római kori latin neveket és a középkori latinságban használt elnevezéseket, hiszen ezek eltérnek egymástól (pl. Gyôr a római kori latin nevén Arrabona, a középkori latinságban Jaurinum). Sajátságos réteget képeznek a török elnevezések, amelyek néha mai nemzetiségi helységnevekben élnek tovább Például Érd török neve Hamzsabég/ Hamzabeg volt, ezt vették át a török kor után betelepült nemzetiségek, így lett a német neve Hanselbek, a horvát neve pedig Andzabeg. Adony török neve az eredetileg lélekmentô (ma úszómester) jelentésú Cankurtaran volt, ebből keletkezett a horvát neve, ami Džankutaran. A magyarországi zsidóság nem számít nemzeti kisebbségnek. De a körükben korábban általánosan használt jiddis nyelven is jelentôs számú helységnévváltozat létezik, amelyet a magyarországi zsidók külföldön élő leszármazottai a mai napig is használnak, illetve a különbözố célú zsidó település-nyilvántartások internetes oldalai ezeket feltüntetik (pl. Kerestir/ Bodrogkeresztúr, Kleynvardeyn/ Kisvárda, Kalev/Nagykálló).

A legtöbb idegen névváltozata minden bizonnyal Pécs városának van. A nemzetiségi nyelveken összesen 20, de ha még hozzá számítjuk a nem nemzetiségi idegen nyelvú névváltozatokat is, akkor 32! A névalakok egy része a magyar Pécs névnek egy változata, más része pedig Pécs középkori latin nevének („öt templom”) a tükörfordítása. Pécs elnevezései az elismert nemzetiségi nyelveken:

- Fünfkirchen (német, irodalmi)

- Fünfkirige, Fünfkiriche, Fenfkiricha (német, helyi nyelvjárás)

- Finfkirch (német, villányi nyelvjárás)

- Pečuh (horvát, irodalmi)

- Pečuj (horvát, nagyhajmási nyelvjárás)

- Pečuv (horvát, hercegszántói nyelvjárás)

- Peču (horvát, kökényi nyelvjárás)

- Petocríkva (horvát, szentpéterfai nyelvjárás)

- Печуј (szerb)

- Pisju (roma, beás)

- Pechuy, Pecho, Pech (roma, romani)

- Пейч (ruszin)

- Pätkostolie (szlovák)

- Pecz (lengyel, mai)

- Pięciokościoły (lengyel, régies)

- Peci (román)

Pécs elnevezései egyéb idegen nyelveken:

- Pětikostelí (cseh)

- Pēča (lett)

- Pėčas (litván)

- Peçuy, Peç (török)

- Cinquechiese (olasz, régies)

- Cinq-Églises (francia, régies)

- Vyf Kerken (flamand, régies)

- Quinque Basilicae, Quinque Ecclesiae (latin, középkori)

- Sopianae (latin, ókori)

- Fetsh (שטע, jiddis)

\section{Következtetések, feladatok}

A Földrajzinév-tár adatbázisába felvett nagyszámú nemzetiségi helységnév egy jóval nagyobb névhalmazt jelent, mint ami a hivatalosként elfogadható nemzetiségi helységnevek köre. Ezért véleményem szerint feltétlenül szükséges elôbb azon települések körének a meghatározása, ahol megállapítható hivatalos nemzetiségi helységnév. A történelmi és a szomszéd településekre vonatkozó nemzetiségi helységnevek elkülönítése mellett minél több tényezőt kellene figyelembe venni. Nem elég pusztán a népszámlálási adatok alapján egy nemzetiségi részarányt kikötni, a nemzetiségi lakosság abszolút létszámát is figyelembe kellene venni, továbbá fontos volna megvizsgálni, hogy van-e nemzetiségi oktatás, múködnek-e nemzetiségi civil szervezetek, egyházak, önkormányzatok, van-e bármilyen megnyilvánulása az élố nemzetiségi kötốdésnek, van-e igény a nemzetiségi önazonosság kinyilvánítására. Saját vizsgálataim szerint Magyarország 3154 önálló helysége valamint a jól elkülönüló helységrészek közül mintegy 600-700 nemzetiségi kötôdésû településrôl beszélhetünk, ahol indokolt lehet hivatalos nemzetiségi nyelvú helységnév megállapítása.

Az adatbázisban szerepló nemzetiségi földrajzi neveket anyanyelvi, nemzetiségi, nyelvészeti szakértôkkel feltétlenül ellenôriztetni kell, hogy a helyi használatnak legmegfelelôbb, nyelvileg leghelyesebb, történetileg leghitelesebb névalak kerüljön kiválasztásra. Ennek a szabványosítási folyamatnak a végén következhet be a nemzetiségi nyelvú hivatalos földrajzi nevek megállapítása, ahogy azt a már hivatkozott kormányrendelet megfogalmazza.

\section{Irodalomjegyzék}

Andócsi János 2012. Az anyanyelv használatának jogi lehetôségei Horvátországban. In Térvesztés és határtalanítás. A magyar nyelvpolitika 21. századi kihívásai. Nemzetpolitikai Könyvek 1. Nemzetpolitikai Kutatóintézet. Lucidus Kiadó, Budapest.pp. 271-287. https:// bgazrt.hu/wp-content/uploads/2018/07/ Tervesztes-es-hatartalanitas.pdf, utolsó elérés: 2019. június 7 . 
Andrássy György 2012. Lehet-e a magyar hivatalos nyelv egyes szomszédos államokban? A nemzetközi jog lehetốségei. In Térvesztés és határtalanítás. A magyar nyelvpolitika 21. századi kihívásai. Nemzetpolitikai Könyvek 1. Nemzetpolitikai Kutatóintézet. Lucidus Kiadó, Budapest. pp. 80-100. https:// bgazrt.hu/wp-content/uploads/2018/07/ Tervesztes-es-hatartalanitas.pdf, utolsó elérés: 2019. június 7.

Arató (Rosenberg) Mátyás 2013. A beás nyelvjáráskutatás elổzetes tapasztalatai. In Arató Mátyás - Cserti Csapó Tibor (szerk.) Gypsy Studies - Cigány tanulmányok 30. Romológia „akkor és most” romológusok második szakmai konferenciája. Konferenciakötet. Pécsi Tudományegyetem BTK NTI Romológiai és Nevelésszociológiai Tanszék - Romológiai Kutatóközpont - Wlislocki Henrik Szakkollégium, Pécs. pp. 47-65.

Balogh Lajos - Ördög Ferenc (szerk.) 1985. Komárom megye földrajzi nevei. Magyar Nyelvtudományi Társaság, Budapest.

Beregszászi Anikó - Csernicskó István - Ferenc Viktória 2014. Nyelvi jogaink és lehetốségeink. Útmutató és tájékoztató a nyelvtörvény gyakorlati alkalmazásához kárpátaljai magyaroknak, Bethlen Gábor Alapkezelố Zrt. http://www.kji.hu/wp-content/ uploads/2017/10/10-es-csatolmany.pdf, utolsó elérés: 2019 . június 7.

Bundesgesetzblatt 2000. Bundesgesetzblatt für die Republik Österreich. Ausgegeben am 21. Juni 2000. 170. Verordnung: Topographieverordnung-Burgenland http:// mtatkki.ogyk.hu/uploads/files/olvasoszoba/ ogyk/jogtar/pdf/A $2000 \quad 170$ V.pdf, utolsó elérés: 2019. június 7.

Cartographia 2015. Schulatlas für die ungarndeutschen Nationalitätenschulen. Cartographia Tankönyvkiadó Kft., Budapest.

Davidov, Dinko 1990. Spomenici Budimske eparhije. Prosveta, Beograd.

Gyivicsán Anna - Krupa András 1997. A magyarországi szlovákok. Változó világ 16 Uttmutató, Budapest. pp. 16-20.

Gyivicsán Anna (szerk.) 1996. A magyarországi szlovákok népi kultúrájának atlasza. Szlovák Kutatóintézet, Békéscsaba.

Hajdú Mihály (szerk.) 1982. A Csepel-sziget helynevei. Akadémiai Kiadó, Budapest.

Hambuch Géza (szerk.) 1992. Deutscher Kalender 1993. Verband der Ungarndeutschen, Budapest. pp. 286-291.

Karagić, Mijo (szerk.) - Mokuter, Ivan 1986 Naši radovi. Izdanje Demokratskog saveza Južnih Slavena u Mađarskoj, Budimpešta.

Kemény István (szerk.) 2000. A magyarországi romák, Változó világ 31. Press Publica, Budapest. p. 35.

Korm.-rendelet 2007. 303/2007. (XI. 14.) Kormányrendelet a magyarországi hivatalos földrajzi nevek megállapításáról és nyilvántartásáról https://net.jogtar.hu/ jogszabaly?docid=a0700303.kor, utolsó elérés: 2019. június 7.

Kozar-Mukič, Marija/Mukicsné Kozár Mária 1984. Etnološka topografija slovenskega etničnega ozemlja - 20. stoletje, Slovensko Porabje / A szlovén etnikai terület néprajzi topográfiája - 20. század. Edvard Kardelj Egyetem Bölcsészettudományi Karának Tudományos Intézete - Savaria Múzeum, Ljubljana - Szombathely.
KSH 1995. A Magyar Köztársaság helységnévtára 1995. Központi Statisztikai Hivatal, Budapest.

KSH 2014. 2011. évi népszámlálás. 9. Nemzetiségi adatok. Központi Statisztika Hivatal, Budapest. http://www.ksh.hu/ docs/hun/xftp/idoszaki/nepsz2011/ nepsz_09_2011.pdf, utolsó elérés: 2019. június 13.

KSH 2019. Magyarország Helységnévtára A helységek - helységnévtáblára kiírt nemzetiségi neveinek listája, Központi Statisztikai Hivatal. http://www.ksh.hu/apps/ hntr.nemzetisegi?p lang=HU, utolsó elérés: 2019. június 12 .

Kult. Min. 1978. Javaslat a nemzetiséglakta települések helységneveinek két-, illetve többnyelvú kiírására. Összeállította a Kulturális Minisztérium Nemzetiségi Osztálya. Kézirat. Budapest.

Lábadi Károly 2003. Nyelvtörvények, nyelvi jogok Horvátországban. In Nádor Orsolya - Szarka László (szerk.): Nyelvi jogok, kisebbségek, nyelvpolitika Kelet-KözépEurópában, Akadémiai Kiadó, Budapest. pp. 176-189. http://adattar.adatbank. transindex.ro/tanulmany/11 Labadi Karoly. htm, utolsó elérés: 2019. június 7.

Lázár 1528. Tabula Hungariae. Lázár deák tér képe. Ingolstadt. https://lazarterkep.oszk. hu/hu, utolsó elérés: 2019. június 12

Lexicon 1773. Magyarország helységeinek 1773-ban készült hivatalos összeírása. Reprint kiadás. Kiadja a magyar békekül döttség 1920, Budapest. http://mtdaportal extra.hu/ADATBANK/Lexicon lcorum.PDF utolsó elérés: 2019. június 12.

Mandić, Živko 2005. Hrvatska imena naseljenih mjesta u Madžarskoj. Folia onomastica croatica. Knjiga 14, Hrvatska Akademija Znamosti i Umjetnosti, Zagreb. pp. 37-128.

Mapire 2019. Mapire - Történelmi Térképek Online. Hungaricana Közgyújteményi portál. Arcanum Adatbázis Kft. https://mapire. eu/hu/, utolsó elérés: 2019. június 12.

MNT 2012. A Magyar Nemzeti Tanács hivatalos nyelvhasználati stratégiája 2012-2017. p. 14. http:/www.mnt.org.rs/dokumentum/ nyelvhasznalati-strategia-2012-2017, utolsó elérés: 2019. június 7.

Monit. oficial 2001. Monitorul oficial al României Anul XIII - Nr. 781 http://mtatkki. ogyk.hu/uploads/files/olvasoszoba/ogyk/ jogtar/pdf/HG_2001_1206.pdf, utolsó elérés: 2019. június 7

Müller Márta 2013. Bajor utcanevek egy magyarországi német településen. Névtani Értesítổ 35. pp 97-107.

Nariad. vlády 1999. Nariadenie vlády Slovenskej republiky z 25. augusta 1999 , ktorým sa vydáva zoznam obcí, v ktorých občania Slovenskej republiky patriaci $\mathrm{k}$ národnostnej menšine tvoria najmenej $20 \%$ obyvatelstva http://mtatkki.ogyk.hu/ uploads/files/olvasoszoba/ogyk/iogtar/pdf/ SK 1999221 Rend.pdf, utolsó elérés: 2019. június 7 .

Orsós Anna 2003. Beás-magyar kisszótár Dávid Oktatói és Kiadói Bt., Kaposvár.

Pesti János (szerk.) 1982: Baranya megye földrajzi nevei I-II. Baranya megyei Levéltár, Pécs.

Pesty 1984. Pesty Frigyes kéziratos helynévtárából. Pest-Pilis-Solt vármegye és kiegészítések. Pest megyei téka 6. Az
Országos Széchenyi Könyvtár Kézirattári Pesty Frigyes gyújteményének 33. kötetébốl közreadja Bognár András. Pest megyei Múvelổési Központ és Könyvtár Szentendre. Elektronikus megjelenítés NKÖEOK Szerkesztốség. 2007. https:// www.sulinet.hu/oroksegtar/data/megyek oroksege/Bacs_kiskun megye/pages/Pest pilis_solt/000_konyveszeti_adatok.htm, utolsó elérés: 2019. június 13.

Petrusán György - Martyin Emília - Kozma Mihály 1999. A magyarországi románok. Változó világ 29. Press Publica, Budapest. p. 19.

Regényi, Isabella - Scherer, Anton 1980. Donauschwäbisches Ortsnamenbuch. Arbeitskreis Donauschwäbischer Familienforscher, Darmstadt.

Sasi Attila (szerk.) 2014. Die Deutschen in Ungarn, eine Landkarte mit den deutschen Ortsnamen / A magyarországi németek térképe. 3. Auflage/3. kiadás. Neue-ZeitungStiftung - Corvina, Budapest.

Törvény 1898. 1898. évi IV. törvénycikk a község- és egyéb helynevekrốl. https://net. jogtar.hu/getpdf? docid=89800004.TV\&ta rgetdate $=\&$ print Title $=1898 .+\% \mathrm{C} 3 \% \mathrm{~A} 9 \mathrm{vi}+$ IV.+t\%C3\%B6rv\%C3\%A9nycikk\&referer= $1000 \mathrm{ev}$, utolsó elérés: 2019. június 12.

Uradni list 1991. Uradni list Republike Slovenije. Ljubljana, sobota 28 . decembra 1991. https://www.uradni-list.si/ pdf/1991/Ur/u1991033.pdf, utolsó elérés: 2019. június 7

Végh József - Ördög Ferenc - Papp László 1981. Tolna megye földrajzi nevei. Akadémiai Kiadó, Budapest.

Weidlein, Johann 1980. Die Schwäbische Türkei. Ungarndeutsches Sozial- und Kulturwerk, München.

Zákon 1994. Zákon Národnej rady Slovenskej republiky o označovaní obcí v jazyku národnostných menšín http://mtatkki. ogyk.hu/uploads/files/olvasoszoba/ogyk/ jogtar/pdf/SK 1994191 Tv.pdf, utolsó elérés: 2019 . június 7.

Zsámboki Erdély 1566. Transilvania. Zsámboki János/Sambucus, Wien https://maps. hungaricana.hu/hu/HTITerkeptar/714/, utolsó elérés: 2019. június 12.

Zsámboki Magyarország 1566. Ungariae Tanst. Descriptio nunc correcta ... . Zsámboki János/Sambucus, Wien https://maps. hungaricana.hu/hu/HTITerkeptar/351/, utolsó elérés: 2019. június 12.

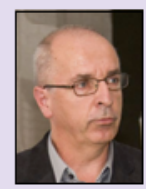

Sasi Attila

térképész

Lechner Tudásközpont Térinformatikai Osztály attila.sasi@lechnerkozpont.hu 